into the valley of the Ebro. Again, in Languedoc and Dauphine. Near Nice, in the Maritime Alps, and in Lombardy. In Switzerland, in Sicily, and in Turkey. Not to speak of Egypt, where this rock has long been known to exist.

A. D. ACWORTH.

\title{
NOTES ON THE GLACIAL PHENOMENA OF WASTDALE, CUMBERLAND.
}

\author{
By Edw. Hulr, B.A., F.G.S.
}

DEAR Str, - I had hoped this year to have been able to extend over the Northern portions of the Cumbrian mountains some observations on Glacial Vestiges which I made in 1859 over the southern slopes of the same range, and communicated to the Edinburgh New Philosoplical Journal.* I have only, however, been permitted to investigate a very small tract along the western slopes; but though limited to this, the following notes may not be without value, as there are few observations as yet recorded of the evidences of extinct glaciers in the English Highlands.

I may preface my remarks by observing that the first notices of glacial phenomena in the Lake district were made by Agassiz and Puckland in their general survey of the evidences of extinct glaciers in the British Islands; but they were accompanied by very few special examples. It is not, however, from any want of striking instances that till lately they have been passed by almost without notice. Every valley which descends from the central watershed, presents the features of a glacier-channel, and is well furnished with roches montonnées, perched blocks, moraines, and striated rock-surfaces. Even the lakes, which are the special feature of this region, are in many instances due to the presence of terminal moraines, which have acted as embankments to the waters. In addition to the instances which I have already enumerated, I may now add that of Wast Water, " the wildest, the deepest, the most impressive of all our lakes, over whose surface the winter's frost cannot spread a crust."

Wastdale leads up from the undulating tract of New Red Sandstone which lines the coast into the very heart of the highest mountains. At its head stands Great Gable, an elevation conspicuous for its pyramidal outline as seen from the west. On the right of this rises Scawfell, the culminating point of England, 3166 feet, throwing out some limbs, like grent buttresses, with very gracefully curved

* Vol. xi. Glacial striæ have also been observed by Professor Phillips on the limestone of the southern coast, and by Mr. Bryce, near Kendal. In a letter to the author in $1860, \mathrm{Mr}$. W. Longman states how much he was struck by the glacial phenomena in several localities in the Lake district. 
outlines. Its western shoulder forms "The Screes," a range of precipitous cliffs overtopping banks of shingle which sweep down in one sheer unbroken plane into the deep waters of the lake. The position of the rocks on each side of the lake, together with the straightness of the southern line of cliffs, are in favour of the supposition that Wastdale has been formed along the line of a great fracture. Yewbarrow, on the northern side, is one of the most picturesque hills I have ever seen. Capped by vertical cliffs, which ascend almost to a point, its sides fall away on either hand in exceedingly graceful outlines, to which I would draw the attention of Mr. Ruskin, as they illustrate his doctrine of the curves of nature. It is in vain for me to attempt to describe the various aspects which the landscape here assumes, with the most solemn and wild features she has also combined her most graceful proportions.

On my former visit to the Lakes, I became convinced that this mountain-chain had been a "centre of dispersion," from which glaciers descended in every direction seaward. In Grisedale, I had found striæ ranging north. In the neighbourhood of Ambleside, south and south-east; but I had never an opportunity presented of observing a westerly striation. I was therefore delighted (the less enthusiastic reader will, I hope, pardon the use of the only word expressive of my feelings on the occasion) on finding just above the village of Strands, near the western entrance of Wastdale, a boss of syenite polished, and distinctly marked with grooves ranging out to

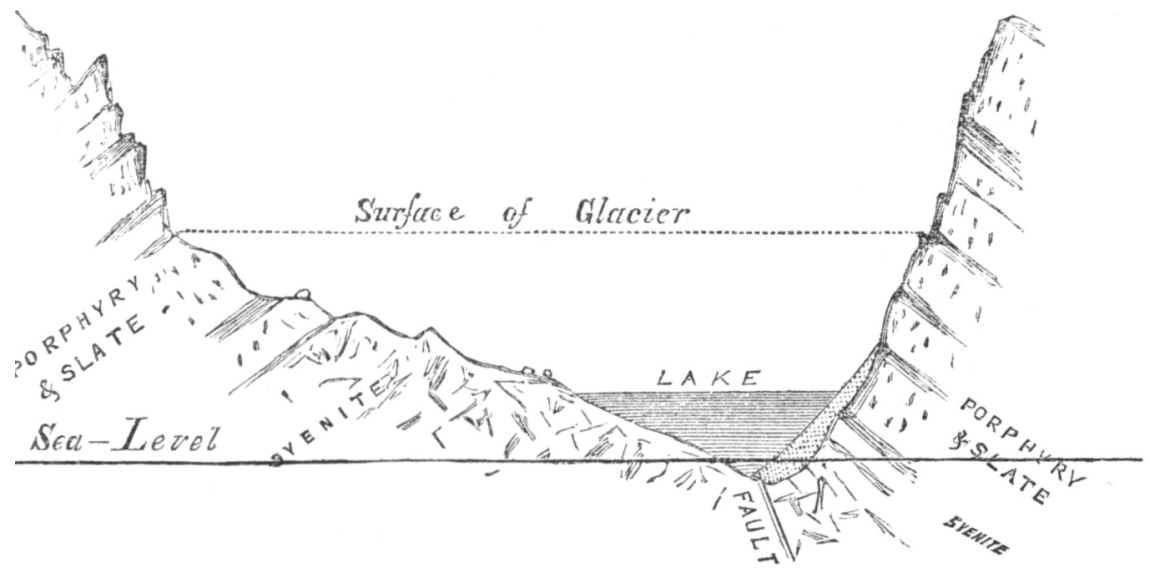

sea. Further np the valley, I obtained at least six good observations, and the invariable direction was west, or nearly so. The highest observation was made on porphyry, near the foot of Yewbarrow.

The upper limit of the glaciation, along the centre of the dale, was easily ascertained. The rocks, from the edge of the lake up to an 
elevation of about 800 feet above its waters (estimated), were found to be all clearly ice-moulded, that is to say, worn down into smooth mammillated bosses, often showing striations or grooves; but above this line, which appeared very constant for a long distance, the rocks assume the form of orags, sharp and precipitous. (See figure.) The contrast here alluded to may be well observed on the flanks of the rock-masses west of Greendale. And if we suppose that it marks the upper limits of the glacier, we have a measure of the thickness of the ice at this point. The level of the lake is 160 feet above the sea, and its depth 270 feet, or 110 feet below this. This would give for the total thickness of the ice $800+270=1070$ feet, and for its surface, $800+160=960$, or 1000 feet above sea-level. By similar admeasurements, it is probable the thickness of all the extinct glaciers may be calculated.* The length of the glacier (measured from its nevée, at Wastdale Head, to the point where the first traces of glaciation were observed) appears to have been upwards of six miles, and it had its source amongst the snow-clad heights of Scawfell, Yewbarrow, Kirkfell, and Great Gable. From these reservoirs also proceeded, in all probability, glaciers into Ennerdale, Crummockdale, and Borrowdale.

In Wastdale, there is a remarkable scarcity of some of the more prominent productions of glaciers, at least as compared with many of the neighbouring valleys. There is very little drift, or moraine matter, with one exceptional case presently to be noticed, and perched blocks are of rare occurrence. In general, the native rock is bare, but invariably iceworn from the water's edge up to the limit already assigned.

But the large moraine which has been thrown across the valley near its entrance, and which forms the embankment for the lake, amply compensates for the absence of these glacial monuments in other parts of the valley. Viewed from above, it looks like un artificial bank, as its upper surface has been levelled, and planted with trees. It is nearly 500 yards in length, with a breadth varying up to 100 yards, and a height of sixty feet above the surfuce of the lake. The water finds an ontlet in a channel between the southern end of the moraine and the base of the Screes, which here tower aloft to a height of about 1000 feet, a wall of beetling cliffs. I satisfied myself, by a careful inspection, that this bank, to which the lake, at least partially, owes its existence, is a true terminal moraine. It is either this or man's work, and the latter it certainly is not. It is composed of gravel and sub-angular or rounded pebbles in a clayey matrix, also enclosing large blocks of porphyry and other rocks. To the south, it terminates, as already stated, opposite the base of the Screes, and its northern extremity reposes upon ice-moulded bosses of syenite. The period at which this moraine was thrown across the valley was probably that third stage in the changes of the Glacial Epoch, when, after

* Sinvilar admeasurements have been made in North Wales by Professor Rámsay.-Peaks, Pccsses, and Glaciers. 
the deposition of the Boulder clay around the flanks of the hills-to an elevation in Cumberland of about 1000 feet-the land was elevated, and glaciers again descended the valleys and "ploughed out the drift." It is only on such a supposition, as deduced by Professor Ramsay from his observations in North Wales, that we can account for the existence of old moraines at levels so far below that attained by the Boulder clay.

I remain, dear Sir, yours faithfully,

Edward Hulc.

\section{FOSSILS OF NORTH BUCKB AND THE ADJACENT COUNTIES.}

\section{By J. H, Macalister.}

As the geographical distribution of fossils is always an interesting subject, it has occurred to me that a few words on the Oolitic fossils of this part of England, not much visited by geologists, may be acceptable to, at least, some of the readers of the "Geologist." It will not be my intention in this paper to treat so much of the geological features of the country, as to give complete lists of the organic remains which have been found by myself and a few others in the various strata of this district. The Oolites of North Bucks and Northampton, though of course presenting, for the most part, the usual character of the system as represented in other Oolitic districts of England (being, as they doubtless are, merely a continuation of those of Oxfordshire, \&c.), yet possess several points of interest peculiar to themselves. The identity of the "Northampton Sands" (formerly classed with the Lias)* with the Stonesfield Slate of Oxfordshire and Gloucestershire, and constituting the Lower Zone of the Great Oolite, the importance of these "sands" as an iron ore; the occurrence of land-plants similar to the Stonesfield specimens in the Forest-marble of the neighbourhood of Wolverton; the extensive development of the Kimmeridge Clay at Hartwell ; and of the Great Oolite further north; - all these facts combine to invest these beds with much interest, both to the geologist and the palæontologist.

The strata which I am about briefiy to describe, and whose organic remains I shall enumerate, are the following :-

UPPER OOLITEB.

MIDDLE OOLITES.

Portland rock.

Kimmeridge elay.

Oxford clay.

- So classed hy Dr. Wright, being separated by hin from the Inferior Oolite, which they formerly were supposed to represent.

VOL. IV. 